Volume 1

Issue 1 Transformative Possibilities:

Transcending Interlocking Boundaries

\title{
Comparative Colonialsims: Variations in Japanese Colonial Policy in Taiwan and Korea, 1895 - 1945
}

\author{
Gunnar Abramson \\ Portland State University
}

Follow this and additional works at: https://pdxscholar.library.pdx.edu/mcnair Let us know how access to this document benefits you.

\section{Recommended Citation}

Abramson, Gunnar (2004) "Comparative Colonialsims: Variations in Japanese Colonial Policy in Taiwan and Korea, 1895 - 1945," PSU McNair Scholars Online Journal: Vol. 1: Iss. 1, Article 5.

https://doi.org/10.15760/mcnair.2005.11

This open access Article is distributed under the terms of the Creative Commons Attribution-NonCommercialShareAlike 4.0 International License (CC BY-NC-SA 4.0). All documents in PDXScholar should meet accessibility standards. If we can make this document more accessible to you, contact our team. 
Portland State University McNair Research Journal 2004-2005

Comparative Colonialsims: Variations in Japanese Colonial Policy in Taiwan and Korea, 1895 - 1945 By

Gunnar Abramson

Faculty Mentor:

Linda Walton

Citation: Abramson, Gunnar. Comparative Colonialsims: Variations in Japanese Colonial Policy in Taiwan and Korea, 1895 -1945. Portland State University McNair Scholars Online Journal, Vol. 1, 2004-2005: 11-37. 


\section{Comparative Colonialsims: Variations in Japanese Colonial Policy in Taiwan and Korea, 1895 - 1945}

by Gunnar Abramson

Faculty Mentor : Linda Walter

Japan's seizure and early governance of Taiwan and Korea, both of which would become its most important subject territories, is widely understood by historians as being informed by the context of late nineteenth century "new" imperialism. The belief, widely held in the West at the time, that the measure of a nation's strength was dependent on the reality of its political control over territories outside of the metropole, was accepted by Meiji era Japanese elites. Believing that they had, in large part, successfully navigated the inaugural decades of a wide ranging policy of promoting economic modernization, these elites could more confidently hope that their nation's recent technological, educational, and economic strides would translate into a capacity to project power outwards. Based on such confidence that, owing to it's growing modernization, Japan had truly escaped the lot of the colonized in Asia and, moreover, could enter the ranks of the colonizing nations, rhetoric justifying colonialism on nation-strengthening grounds was more attractive near the century's close.

Japan's adoption of this overall justification for movement overseas and its subsequent expansion was consistent with the dominant trend of the age during which both took place. Both time and circumstance affected the creation of the early Japanese Empire to make its composition rather inconsistent with other empires of the period. Also, Japan's rather late entry onto the modern world stage towards the latter portion of the second half of the $19^{\text {th }}$ century - after over two centuries of prior European colonial activity - precluded a wider array of territory available for the taking. Additionally, Japan's lesser economic power relative to expanding Western nations in the late 1800s meant a comparative inability to sustain colony-acquiring expeditions far from home. Taken together, Western domination of empire building in the Asia-Pacific region and Japan's limited reach steered the country's earliest land grabs toward the region geographically nearest Japan itself, rather than toward more far flung locales. The nearness of Japan's earliest major colonies, the first, an island due south of the home islands and just off the coast of China, and the second a peninsular

nation nearer Japan than any other country, was crucial to their conquest by Japan. ${ }^{1}$ Close proximity to the conqueror obviated the need for Japan to mount a far off campaign of conquest. Indeed, the 
close location of Taiwan and Korea meant that Japan's initial seizure of them, as well as it's ability to sustain political and military control over them, was never much hindered by the longer supply lines to the colonies that were endured by some Western powers. It is feasible to interpret the seizure of Taiwan and Korea as at least partially due to both lands being among the few portions of Asia available for colonial acquisition by the time of the emergence of a Japanese willingness and ability to expand. Security concerns also played a role in Japan's choice of early colonies, especially in the case of Korea. Japan's expansion onto the peninsula was as much a function of attaining total control over a piece of strategic real estate geopolitically important to the security of the home islands themselves as other motives. ${ }^{2}$

The earliest Japanese colonies were not only geographically close to Japan but culturally close as well, being populated by peoples sharing, most notably, Chinese literary, cultural, and religious affinities such as Chinese ideograms, Confucianism, and Greater Vehicle Buddhism. Japanese colonizers of the late $19^{\text {th }}$ and early $20^{\text {th }}$ centuries did not deny their nation's similarities with their newly won subject peoples and often spoke of a desire to lead Taiwan and Korea out of decrepitude to modernity just as the Japanese themselves had modernized from 1868 onward. Both the main Western justification for colonialism that Japan adopted - which explicitly reserved the right for more advanced peoples to control lesser ones - and the slightly more altruistic tone of the desire to lead fellow East Asians evoked by feelings of racial and cultural similarity, preserved the ultimate power of Japan. ${ }^{3}$ Japan's governance of Taiwan and Korea was informed by both kinds of rhetoric. The more European style of colonial governance, closer to the first justification, guided Japanese colonial administrators - especially early on. The subject peoples' inherent inferiority to their Japanese masters was believed to make an administration which moved colonial peoples only gradually toward political, cultural, and social assimilation with metropolitan Japanese, preferable to one of rapid integration of the colonized with the colonizer. The other approach, which merely emphasized Japan's cultural sameness with its Asian colonies during the earliest period of Japanese colonialism, later grew more insistent about the Asian provenance of the Empire. As developments in the wider world eroded Japanese colonizers' confidence that sufficient time needed to work would be available for the earlier colonial policy, in the European vein of association, this approach turned into justification for a change in policy from association to fast-track assimilation.

Though this shift in Japan's approach to the governance of its colonies took place in both Taiwan and Korea, significant differences in the effect of each approach underscores the very different environments in each location and the consequently different challenges, peculiar to each, 
that faced the colonizer. The internal makeup of each colony, as well as its immediate pre-colonial history, gives some understanding of these challenges.

Taiwan's peoples presented a heterogeneous population. Though ruled by the mainland Qing dynasty as an adjunct to a coastal province from 1683-1885 and as a province in its own right from 1885 until Japanese occupation, it remained fragmented, restive, and difficult for Chinese administrators to govern. Although the initial years of Japanese administration would also be forced to contend with this traditional Taiwanese resistance to outside authority, the lack of an island wide identity or a pre colonial political order that commanded islanders' allegiances worked to Japan's advantage. Governing Japanese, hoping initially to compel islanders to submit to their authority or, slightly later, to encourage the islanders' more active support of the colonial infrastructure, therefore did not have to compete against the entrenched, xenophobic, pre-colonial identity that had continued to exist in Korea after it's annexation in 1910. Attitudes on the part of the colonial elite in both Taiwan and Korea were shaped by such basic differences within the colonies themselves as well as by the different ways each possession was conceived of in terms of strategic concerns of the metropolitan government. The Korea Government General, for example, was headed by Army Generals from annexation until the end of WWII. ${ }^{4}$ These Generals rebuffed liberal attempts to reform colonial policy in the 1920s and asserted the appropriateness of their military rule by citing Korea's greater geopolitical importance to Japan's safety over that of Taiwan. ${ }^{5}$ The slightly lower strategic priority given to Taiwan by the military and military-minded civilian policy makers meant that directives from the homeland were more closely followed on the island than on the peninsula.

The often-contrasting policies pursued by Japan in Taiwan and Korea were planned, insofar as there was an element of colonial policy that responded to strategic and political concerns in the homeland. The policies were also responses to the reality of the level of acceptance or resistance to Japanese occupation in each of the colonies which was dependent as much on the innate political and cultural idiosyncrasies of each colony as on policies enacted by Japan after colonization.

\section{Taiwan: Frontier Island to Colonial Showcase}

Early Chinese settlement of Taiwan began largely in the early $15^{\text {th }}$ century with the end of earlier Ming Dynasty prohibitions on Chinese maritime activity. The western coast of Taiwan proper, as well as the Peng-hu islands ninety miles from Taiwan between the island and the mainland, became settled by farmers who planted and tilled pristine ground there during the spring and summer months before retiring to their homes on the mainland during winter. ${ }^{6}$ Fisherman from 
Fujian, the Chinese province directly across from Taiwan, also began living in the Peng-hu islands while they plied the surrounding waters every year during peak fishing season. During this time of seasonal Chinese settlement, however, no formal Chinese government writ ran on either Taiwan or nearby islets. The fact that Taiwan existed beyond the grip of the Emperor was at least a partial incentive for Chinese to begin immigrating. Other motives, at least early on, naturally included the plentiful amount of land available for the taking and the promise of few obstacles to settlement, save for resistance from scattered inland aborigines. The arrival of the Dutch East Indies Company on the island in 1624 accelerated the process of Chinese migrations across the Taiwan Strait. Though requiring up to ten percent of the crops yielded by both permanently settled and migrant Chinese farmers and requiring that those hunting the island's deer first obtain licenses, which became a key source of revenue to the Dutch, Chinese migration continued. By some estimates Taiwan's Chinese population grew as much as fifty thousand during the period. ${ }^{7}$

Sent to Taiwan via self exile from a mainland invaded by ethnic Manchus - founders of the Qing Dynasty -Ming Dynasty loyalist Zheng Chenggong evicted the Dutch in 1661 and converted Taiwan into a redoubt from which he hoped to take back the mainland for the Ming. After Zheng's death a year after his rule on the island, internal power struggles weakened his followers through the heavy-handed reaction of the Qing to political supporters of Zheng's on the Fujian coast. This amounted to forced relocation and swelled Taiwan with even greater numbers of refugees. ${ }^{8}$

The weakening of Taiwan's administration among Zheng's followers caused serious defections to the mainland within the armed forces - the centerpiece of any realistic bid for reclamation of China - precipitated eventual collapse in 1683.' The victorious Qing opted, largely at the behest of Shih Lang - the conqueror of Taiwan for the mainland and former lieutenant of Zheng's - to rule the island as a district of Fujian Province.

Taiwan soon gained a reputation as a hardship post for Qing administrators. Clashes between Han Chinese settlers and aborigines, riots directed towards representatives of the central government, and conflicts among Han migrants of similar affiliation were commonplace. Over the course of the era of Qing control over the island, Taiwan experienced some 159 disturbances of varying type and size. ${ }^{10}$ Eventually, Taiwan became synonymous with instability and civil disturbance even among mainlanders. The island quickly came to be described as a place of overall lawlessness where, "Every three years [brings] an uprising, every five years [brings] a rebellion."11

The maintenance of central Imperial control over Taiwan was not only made difficult by the lack of central government institutions on the island but also because the migrants, who came to form a 
majority on the island during the Qing period, had an entirely different outlook than Qing civil servants. The so-called Great Tradition, or the normative hierarchy, which denigrated merchants and exalted farmers and the scholarly class had been accepted as the ideal by successive Chinese dynasties after Confucius. It was little followed in Qing dynasty Taiwan, however, which had been populated by Chinese eager to escape the cultural strictures of the mainland. In addition, those brought from the mainland to run what little machinery of government existed on the island were not only of usually lesser quality than their mainland-posted counterparts, but were also products of a civil service that drew upon the Great Tradition for the training of prospective civil servants. Consequently, those agents of the Imperial government on Taiwan believed in the legitimacy of a normative hierarchical system and accompanying worldview entirely appropriate to most of the mainland with the exception of the coastal environs of Fujian. By contrast, most transplanted Taiwanese on the island, by virtue of their having migrated in the first place, at best ignored and at worst saw that system as a wrongful imposition worth rebelling against.

The Imperial government's preference to loosely control Taiwan in order to avoid costly military involvement on the island was tested by the first decades of the 1800s. Western powers began to exert pressure on China for trading rights within the country and Taiwan as well. By the 1860s the island ports of Tamshui and Anping were opened as treaty ports to western merchants, missionaries, and diplomats. In response to the these newcomers arrival, Qing bureaucrats began to fear that diffuse Imperial control over the island could lead to it's seizure by a western colonial power. Such fears did inspire some measures to better fortify Taiwan against invasion by western expeditionary forces but did not prevent interventions by western trading powers in the latter half of the century. ${ }^{12}$ Japan conquered the northern half of the island in response to the deaths of shipwrecked Ryukyuan fisherman in 1874 at the hands of Botan aborigines and France threatened to seize the island as an indemnity after victory over China during the 1884-85 Sino-French War. The gains made by the French impelled some in Beijing to press for the inclusion of Taiwan within China as its own separate province - a move completed by the end of 1885 . $^{13}$ Attempts by Taiwan's first and second Qing Governors to modernize the island laid the first tentative foundations for further achievements to be undertaken during the Japanese colonial period in the form of railroads, telegraph lines, and improved port facilities. Still, Qing power remained weak relative to the rest of China and Taiwan's Chinese population as internally divided as ever. ${ }^{14}$

Taiwan's continued existence as an effective frontier province up to the time of Japanese annexation in 1895 would prove to be a fortuitous reality for incoming Japanese colonial 
administrators. As in all lands newly conquered by expanding powers at the time, a major goal of the Japanese colonial proconsuls was the establishment and maintenance of law and order on the island following their seizure of it. The lack of a coherent Taiwan political identity would ensure no clear focal point of resistance to the imposition of colonial rule during almost the entirety of Japan's dominion over Taiwan. Since Japan, owing to its greater technological and military strength, would succeed in more effectively controlling the island than had ever been possible during the Qing administration, many islanders seemingly acquiesced to the reality of Japanese control. This led to instances of effective anti-colonial resistance dwindling after a few short years. Coupled with native Taiwanese quiescence to Japanese authority, modernization begun under the Qing, but much accelerated under Japan, served as a kind of mandate for Japanese rule on the island. Altogether, Taiwanese came to recognize that outright violence against Japan would ultimately be fruitless. This recognition of the futility of physical resistance set the stage for later reform movements directed toward increasing Taiwanese participation in the island's governance - though strictly within Taiwan's identity as a subject territory.

Japan's decision to intervene on the Korean peninsula, ostensibly to protect Japanese lives and property during the millenarian Tonghak rebellion, occasioned the start of the First SinoJapanese War in 1894. The conflict would ultimately yield Taiwan to Japan as the latter's first Imperial possession. Taiwan was never a real objective of Japan's war aims at the conflict's outset; it was Korea that most concerned military and political planners in Tokyo. The declining fortunes of the Korean Yi Dynasty portended a possible scramble on the part of major colonial nations to attain control of the peninsula. A destabilized Korea lying just across the Tsushima straits from the Japanese home islands was ominous enough to Meiji leaders, but Korea in the hands of a Western power might be disastrous. ${ }^{15}$ The immediate Japanese aim of the hostilities with Qing then, was to forestall Korean domination by a third country. However, as Japanese victories multiplied over the course of 1894 and Qing forces retreated in disarray, pressure mounted within Japan for territorial concessions from the Qing after final victory. Nevertheless, Prime Minister Ito Hirobumi and his Foreign Minister worried about Western intervention should Japan's advance threaten to imperil the Qing hold on power which would endanger the trading interests of Western governments in China. ${ }^{16}$ The government still felt impelled by public demand to gain some territory after hostilities ended. It was believed that Taiwan could be taken without incurring Western intervention. Although high ranking Army commanders, who were disposed toward believing in Korea's greater strategic 
importance, thought the island too inconsequential a prize given Japan's wartime sacrifice, the decision was made and the island was invaded in June, 1895, as peace negotiations occurred. Naval figures, contrasting the opposition to invasion of the island by their Army counterparts, supported Hirobumi's decision and referred back to the effectiveness with which the French were able to blockade the Chinese mainland from the island in 1885. Should Japan not conquer Taiwan now that the time was right, prominent Navy men argued, a Western power could very well do so in Japan's stead and then be in a position to put pressure on the southern home islands of Kyushu and Shikoku, as well as Okinawa. ${ }^{17}$ Ultimately, support for the taking of Taiwan was assured by the acceptance of the Western justification for colonialism by Meiji policymakers as well as by the masses. Bearing in mind that treaties guaranteeing extraterritoriality to foreigners in Japan remained in force in 1895, it was hoped by foreign policy jingoists and political moderates alike that the creation of an empire, run in the style of Western imperialism, could help rescind such treaties. Efficient control over other lands could, by implication, demonstrate Japan's newfound strength and consequently, the treaty's inappropriate application. ${ }^{18}$

Despite the lack of any coordinated opposition to Japan's invasion amongst large sections of the island population, violence was still present at the opening stage of Japan's colonial suzerainty over Taiwan. Expeditionary forces fought village-based guerillas as well as mainland based militias. The entirety of the island was brought under Japanese sway with the taking of Tainan in the south by October of $1895 .^{19}$ In keeping with the early emphasis on military operations and the extraordinary island-wide conditions believed to necessitate them, the first governor-generals of Taiwan instituted a large-scale policy of bandit suppression. ${ }^{20}$ The Triple Guard System predicated a policing of the island using military forces to patrol rural areas and police to patrol the cities while areas between municipal outskirts and open country were the responsibility of either force, depending on need. ${ }^{21}$ Taiwanese casualties mounted and the draconian tactics practiced under the Triple Guard approach, even by most Japanese accounts, did little to dent criminality or antiJapanese agitation in most areas. Sometimes the tactics transformed once placid areas into locales rife with anti-colonial sentiment. ${ }^{22}$

Despite a fairly heavy-handed initial approach toward the local populace, the first two military governor-generals were not entirely focused on achieving control through strictly military means. Islanders wishing to leave after cession to Japan on April $17^{\text {th }} 1895$ would have two years to do so. ${ }^{23}$ The effect of this grace period for out-migration rid the island of Chinese who thought life under Japan was intolerable. Those that stayed were not necessarily pro-Japanese, but those who 
elected to stay on Taiwan after 1897 implied some form of acceptance of Japanese rule. The outmigration of those who would otherwise have fought the new order advanced the cause of supplanting the barely constrained chaos of the Qing period with the order promised by Japan and its earlier colonial bureaucrats, imbued with a belief in "scientific colonialism" and "association."

The arrival of the fourth military governor-general of Taiwan in February 1898, Kodama Gentaro, announced a marked change in the attitude of Japanese authorities to islanders. The days of bandit suppression were brought to a close as well as the Triple Guard System that had attended them. ${ }^{24}$ In place of counter-insurgent operations, the new Governor and his civilian chief of the Civil Affairs Bureau, Goto Shimpei, embarked on a different program. The new order took much from the commonly held doctrine of gradual assimilation, common among colonial theories of the day, as well as from Goto's fondness for applying "scientific principles" to the domination of subject peoples. $^{25}$

Goto had studied medicine in Germany; his belief that biological laws could be applied to politics as well as the physical world may have originated there. Indeed, some historians have noted intriguing parallels between Goto and Bernhard Dernburg of brief German colonial fame. Both men shared an interest in governing territory as a kind of laboratory within which colonial administrators could interpret the outcomes of specific policies similar to the way technicians could determine the validity of a hypothesis through experimentation. ${ }^{26}$ To Goto, successful experimentation followed data collection and good synthesis of the accurate information collected. Visitors to his quarters in Taipei - renamed Taihoku after 1895 - were struck at his collection of works on colonial theory from a wide variety of sources. The large library, fairly comprehensive for the time, was just one indication that Goto's lessons to his subordinates on the importance of information were wholeheartedly followed by the man himself. ${ }^{27}$ As much a part of his general approach to colonial civil administration, however, was his belief in the inefficacy of a colonial government pursuing too fast a policy of assimilating a subject populace into mirror images of those in the metropole. Like almost all of his compatriots in the Government-General, Goto believed that the ultimate goal of Japan's colonial endeavor, aside from resource extraction and occupation of areas of strategic import, was assimilation of the natives into normative Japanese. In this, he favored a gradual process. Before the 1930s, he and other officials, in both Taiwan and later in Korea expected that true assimilation might be a process of hundreds of years. ${ }^{28}$ It followed from this reasoning that pushing for that ultimate objective unduly hard or fast might engender widespread rebellion of the native elites that could 
then imperil Japan's hold on power in the colonies as a whole. To Goto, this fear of meddling too far or too fast in the traditions of Japan's conquered subjects was due to two beliefs. One was that only sufficient time could bring about a colonial peoples' social and cultural absorption into the metropole. Another was his acknowledgement of the effect of the marked cultural similarities to Japanese that the Taiwan Chinese had. ${ }^{29}$ Japanese colonial policy did not have to move too fast, he and his successors opined, as unlimited time would be available. Goto shared this conceit with other early Japanese colonizers. More interestingly, according to Goto, Chinese cultural affinities with Japanese meant that the majority of Taiwan's inhabitants were already well positioned for assimilation even prior to Japan's arrival on the island, thus Japan did not have to move too quickly to achieve its assimilationist goal. ${ }^{30}$

During his tenure as head of Taiwan's civil affairs planning, Goto combined, in a series of policies, his appreciation of the Asian cultural provenance of the island's Chinese with his desire to avoid unduly antagonizing the populace to the ultimate ideal of a Taiwan joined culturally to the home islands. The first policy was both a reaction to the ineffectiveness of the Triple Guard System that had taxed Japanese troops and civilian police and was a reflection of Goto's belief in the wisdom of perpetuating native traditions where they happened to converge with Japanese interests. The pao-chia system of household and village responsibility and security had been utilized by Taiwan's Chinese from the very beginning, having been first utilized on the Chinese mainland since the Qing takeover in 1644. Despite sometimes being impossible for the Qing to implement effectively, given the size of the Chinese landmass, the system as transplanted to Taiwan proved more effective, given Taiwan's smaller area. Abortive attempts undertaken from 1895 - 1898 to organize "self-defense associations" within villages targeted by anti-Japanese bandits had not gone according to colonial authorities' hopes. Goto, shortly after settling at Taihoku read the Complete Book on Benevolence in the original Chinese, which offered an outline of the pao-chia system. In order to lend momentum to the system's adoption, Goto ordered the work translated into Japanese by the government's Commission for the Investigation of Old Customs. ${ }^{31}$ The formation of individual family properties into groups of ten households each (pao) and ten pao into one (chia), made the villagers themselves responsible for law and order within their local areas. In addition and even more effectively, for Japanese purposes, the system mandated mutual responsibility. ${ }^{32}$ The Government General's adoption of pao-chia, boko in Japanese, meant that Japan now expected that Taiwanese engaged in sedition would incur punishments on their families and neighbors as well as on themselves. 
The Government General's approach to the education of Taiwan's Chinese majority, like the adoption of the hoko system, was also a mixture of more than one assumption of early Japanese colonialism. In the context of education policy, the Government's establishment and encouragement of Common Schools - as distinct from Chinese language private schools - was clearly calculated to instruct Taiwanese students in the proper way of the Japanese subject. To that end, Japanese language instruction was stressed, but colonial teachers were still careful to evince respect for thoroughly Chinese elements such as study of the Classic of Filial Piety. ${ }^{33}$ As much as anything, this and other concessions to the overwhelming Chinese component of the island's majority culture were intended to attract traditional Chinese parents to the idea of sending their young to the common schools and thus slowly starve the private schools of students and the means to continue. ${ }^{34}$ By 1920 , a quarter of Taiwan's school age population was estimated to be attending Japanese run Common Schools. Private school enrollment of Chinese youth would steadily diminish until the government mandated the closing of all private schools in $1943 .{ }^{35}$ More to the point of ameliorating local elites, the Government under Kodama began to fete local notables, holding public ceremonies to recognize them as gentry-scholars of note. Further rewards included the awarding of medallions to mark the occasion. ${ }^{36}$

Dissent from early Japanese colonial thought, as actualized through the policies put into place by Goto and his immediate successors, began in the second decade of the twentieth century. Government bureaucrats, journalists, parliamentarians, and Japanese educated Taiwanese were the principle groups involved in the agitation for change in colonial policy. Perhaps paradoxically, they buttressed calls for change with rhetoric that had been a central component for the rationalization of Japan's Empire since its inception. The principle of isshi-doujin - "impartiality and equal favor [for all subjects of the Emperor]" - had emerged during the Meiji Restoration. The phrase was naturally highly ambiguous. Many have noted in the years following the dissolution of the Japanese Empire that the phrase could be used to press for equal rights for all the Empire's subjects on the one hand, or to emphasize every subject's duties and obligations to the sovereign on the other. To some, true achievement of the principle of isshi-doujin could only come after a period of meaningful interaction between Japanese and colonial peoples. ${ }^{37}$ Mochiji Rokusaburo, an ex-colonial bureaucrat, had echoed sentiments not entirely at odds with early Late Meiji Imperialist notions in his early writings when he tied Japan's international reputation to effective and judicious colonial government, neither too exploitative, nor too lenient toward the natives. By 1912, however, he argued for more specific moves to engender real assimilation, or at any rate, his definition of proper assimilation and 
achievement of isshi-doujin. Mochiji argued that the Japanese colonial elite needed to be less clannish in their living arrangements in the Empire and make an effort to interact with the locales so as to imbue them with "Japanese Spirit." Mochiji would foreshadow the later Pan-Asian movement when he linked successful integration of Asian colonial peoples with Japan - through interaction between both colonized and colonizer - with Japanese expansion itself. ${ }^{38}$ Such thinking went further than Goto's earlier acknowledgement of Asian cultural similarity between Taiwanese and Japanese and the boost such similarities would give to gradual assimilation. Mochiji had implied that future Japanese expansion could be justified as a process of encouraging cooperation among East Asians rather than according to the conventional European view of association.

Within and without the home islands, a legal variant of isshi-doujin began to be voiced by 1910s and 1920s. Legislators, newsmen, and other opinion makers within Japanese society began to question the correctness of limiting the Meiji Constitution's application to the colonies. Advocates of full Constitutional applicability in Taiwan and Korea did not dispute the caveat that only those two colonies could be legally subject to Constitutional largesse, having been colonized in the name of the Emperor. By contrast, Japan's South Pacific Islands - ceded to Japan by League of Nations Mandate - were not obtained by treaty in the name of the sovereign. ${ }^{39}$ They instead remained focused on the contradiction in terms between the letter of the Treaty of Shimonoseki - spelling out Japan's claim to Taiwan - and the Treaty of Annexation, which clarified the nature of Korea's takeover, and the merely selective application of the Constitution in both places. Originally promulgated by the Taiwan Government General in 1896, Law 63 gave sweeping powers to the Governor and contravened the nominal island wide authority of the Meiji Constitution as was stated in the Treaty of Shimonoseki. ${ }^{40}$ After the law's extension in 1899, 1902, and 1905 largely because of perceived lawlessness on Taiwan, the Diet nullified the law and placed the Governorship securely under the Colonial Minister. However, Government House would retain significant powers and apply the Japanese Constitution to island affairs only when it felt the document would not constrain its powers. ${ }^{41}$ Doubtless the effect of pressure by supporters of wider constitutional authority within the so called "sovereign" colonies had little overall effect on the Constitution's place in Taiwan's governance. When compared to the aftermath of such agitation in Korea however, successive Army Governor-Generals were able to make a complete end run around the Constitution by invoking the importance of a free hand as being necessary for effective Japanese control over a location of such high strategic importance. The conventional view of Taiwan's lesser strategic importance within 
Japan may have left Taiwan's overlords with no equivalent excuse for such a salutary avoidance of constitutional authority. ${ }^{42}$

In tandem with reformist efforts directed toward the colonies from within the homeland there emerged a number of groups proposing greater rights for Taiwanese on the island. Initially the groups were led by young Japanese-educated Chinese who, with Government encouragement, called for the abolition of old pre-colonial practices including the wearing of queues, foot binding, and opium smoking. Though not all groups wished Taiwan to be assimilated into another prefecture of metropolitan Japan per se, they nevertheless saw Japan as a giver of modernity to their island and thus were not greatly opposed to Taiwan's legal inclusion within the modern metropole. ${ }^{43}$ However much these groups' specific goals may have differed with the assimilationist rhetoric of Japanese liberal reformers, both sides saw enough commonality of purpose to decide to work together. Yet assimilationist parties on Taiwan would be short lived as the groups quickly ran into vitriolic opposition from Japanese settlers on the island unwilling to entertain the possibility of Taiwanese enjoying, de jure, all the rights they hoped to keep to themselves. Opposition was also great from colonial bureaucrats, many of whom echoed Goto's earlier belief that encouraging such groups would mean the Government's tacit approval of faster assimilationist methods, thus setting the scene for violent native resistance. Still others argued for greater attention to the responsibilities of the colonial subject before equal rights could be discussed. ${ }^{44}$

Discussion over the proper management of colonial peoples from the First World War to the end of the 1920s was made moot by the acceleration of wartime demands following Japan's increased involvement in China. From 1931 on, and particularly from late 1936 until the end of WWII in August 1945, it became readily apparent to colonial governments that the time needed for long-term assimilation to come to fruition could not be assured. Slowly facing this reality and needing to press the colonies into service as sources of men and material for Japan's accelerating war-effort, colonial bureaucracies began implementing the kominka campaign, a program to rapidly turn subject peoples into loyal, thoroughly Japanese, subjects of the Emperor. ${ }^{45}$ The gravity of the international situation Japan now found itself in was first of all reflected in the reversion in 1936 to the appointment of active duty or retired military men as Taiwan Governors after a long period of civilian career bureaucrats holding the post since $1919 .{ }^{46}$ Interestingly kominka in both Taiwan and Korea can be seen as yet another interpretation of the extension of isshi-doujin. In the case of this newest program, however, the aim was not the duplication of the rights available to subjects of the metropole in the colonies but rather insistence on a complete cultural merger of Taiwan and Korea 
in the image of the homeland. Just as importantly, in view of the increasing need for the colonies to shoulder an increasing burden of service to the war effort, the kominka movement pressed for the extension of the full obligations of the Japanese subject to all colonial peoples. In Taiwan the kominka movement was ushered in directly after the arrival of retired Admiral Kobayashi Seizo as Governor General in September 1936. The former Naval Officer proclaimed the inauguration of the movement within the colony as one policy of a three policy agenda to be pursued by his office to further industrialize and fortify the island. ${ }^{47}$ The movement was announced in Korea sometime later through an oath to be made by Koreans affirming their loyalty Imperial Japan as its subjects. ${ }^{48}$ The absence of such an oath in Taiwan has suggested to some observers that the loyalty of Taiwanese toward Japan was never clearly doubted by the colonial authorities, which was not the case of Korea. The latter colony, in spite of equivalent modernization completed under Japanese auspices, continued to demonstrate much antagonism to colonial imposition. Whatever the actual reasons for the use of an oath to assure loyalty in Korea and such a document's absence in Taiwan, the Taiwanese reaction to the sub-movements under the umbrella of kominka policy were different than in Korea even though the government's directives were essentially the same.

Overall, kominka in both colonies consisted of four distinct policies. "Religious reform" meant the discouragement of traditional local beliefs and the substitution of State Shinto in their place. The "national language movement" was intended to denigrate the speaking of local languages in favor of Japanese. The "name changing movement" outlined the mandatory taking of Japanese names by the colonial population, and the "military volunteers movement" was designed to encourage active colonial participation in the war effort through voluntary enlistment in the armed forces. $^{49}$

The "religious reform" plank of the kominka agenda, as pursued in Taiwan, attempted to wean all Taiwanese away from traditional beliefs. The island's Chinese majority saw its traditional religious practices, a syncretic blend of Taoism, Mahayana Buddhism and Confucian morality, criticized by Japanese authorities. Chinese' funerary practices were also inveighed against as "unclean" and the population in question was encouraged to adopt cremation or Shinto funerary rites instead of their longstanding custom. ${ }^{50}$ More draconian tactics pursued by Governor Kobayashi to force Shinto on Taiwanese, which included demolishing Taoist temples, were halted by Kobayashi's successor, though less extreme forms of coercion toward the practice of Shinto continued. ${ }^{51}$ Those in authority hoping to spread Shinto's roots on the island found the way hard going. Local resentment against Government support of Shinto was never as violent as in Korea but 
shortly after this point and the volunteer movement remained in place until early 1945 when the exigencies of the grim war situation for Japan forced the conscription of all male, military age Taiwanese who could be spared for service. ${ }^{57}$

Overall, kominka was never as qualified a success in Taiwan as its planners hoped, but it was much less resisted than in Korea. It is no doubt a credit to the widespread perception among islanders that Japanese colonialism benefited them that, in spite of being forcibly compelled to quite literally become Japanese from 1937-45, Taiwanese would remember Japanese rule almost with fondness in the years directly after the war.

\section{Korea: Hard Going}

In marked contrast to the style of governance employed in Taiwan, Japan generally ruled Korea in the colonial period with a greater resort to force for several reasons. Perhaps most importantly, uncharitable Korean views of Japanese intervention were informed by the pre-colonial political experience - almost entirely the opposite of peripheral Taiwan. Korea, by the beginning of the period of major Western expansion in East Asia, had been securely within the orbit of Qing China. Its own Yi Dynasty, having ruled since 1392, had created a peninsular nation wherein the Great Tradition - never successfully a part of the average Taiwanese world view - was tightly enforced via a four step caste system. ${ }^{58}$ This system also played a leading role in Yi Dynasty Korea's view of its place in the world. The Yi King recognized Korea's place essentially as a highly autonomous vassal state having a tributary relationship with the Qing court. Japan's emergence as a modern state during the 1860s and 1870s was difficult for the Yi court under the rule of Taewongun - regent to the young King Kojong - to even conceptualize, let alone accept. The reason for such difficulty had much to do with Korea's view of China as the center of power in the world. The change in the Japan-Korea relationship from a relationship between a disunited island nation ruled only at some distance by a Shogun and a proud appendicular kingdom to China was occasioned by Japan's notification of the "restoration" of its Emperor and accompanying unification and modernization. The court in Seoul, long used to conducting business through the Japanese daimyo at Tsushima with the occasional recognition of the Shogunate's authority, assumed Japan now wished to claim Korea as its vassalage. Hence, the modern relationship between the two nations began over a dispute based upon two irreconcilable normative views of statecraft and what the term "relations" meant. To a Japan eagerly pursuing recognition as a thoroughly modern power worthy of respect by Western powers, Korean insistence that Japan's pursuit of “modern” bi-lateral relations from a $19^{\text {th }}$ 
shortly after this point and the volunteer movement remained in place until early 1945 when the exigencies of the grim war situation for Japan forced the conscription of all male, military age Taiwanese who could be spared for service. ${ }^{57}$

Overall, kominka was never as qualified a success in Taiwan as its planners hoped, but it was much less resisted than in Korea. It is no doubt a credit to the widespread perception among islanders that Japanese colonialism benefited them that, in spite of being forcibly compelled to quite literally become Japanese from 1937-45, Taiwanese would remember Japanese rule almost with fondness in the years directly after the war.

\section{Korea: Hard Going}

In marked contrast to the style of governance employed in Taiwan, Japan generally ruled Korea in the colonial period with a greater resort to force for several reasons. Perhaps most importantly, uncharitable Korean views of Japanese intervention were informed by the pre-colonial political experience - almost entirely the opposite of peripheral Taiwan. Korea, by the beginning of the period of major Western expansion in East Asia, had been securely within the orbit of Qing China. Its own Yi Dynasty, having ruled since 1392, had created a peninsular nation wherein the Great Tradition - never successfully a part of the average Taiwanese world view - was tightly enforced via a four step caste system. ${ }^{58}$ This system also played a leading role in Yi Dynasty Korea's view of its place in the world. The Yi King recognized Korea's place essentially as a highly autonomous vassal state having a tributary relationship with the Qing court. Japan's emergence as a modern state during the 1860s and 1870s was difficult for the Yi court under the rule of Taewongun - regent to the young King Kojong - to even conceptualize, let alone accept. The reason for such difficulty had much to do with Korea's view of China as the center of power in the world. The change in the Japan-Korea relationship from a relationship between a disunited island nation ruled only at some distance by a Shogun and a proud appendicular kingdom to China was occasioned by Japan's notification of the "restoration" of its Emperor and accompanying unification and modernization. The court in Seoul, long used to conducting business through the Japanese daimyo at Tsushima with the occasional recognition of the Shogunate's authority, assumed Japan now wished to claim Korea as its vassalage. Hence, the modern relationship between the two nations began over a dispute based upon two irreconcilable normative views of statecraft and what the term "relations" meant. To a Japan eagerly pursuing recognition as a thoroughly modern power worthy of respect by Western powers, Korean insistence that Japan's pursuit of “modern" bi-lateral relations from a $19^{\text {th }}$ 
century Western standpoint was actually an attempt to subordinate Korea under an outmoded conception of statecraft, was perplexing. ${ }^{59}$ Clearly, according to many of the Meiji oligarchs then in power, Korean intransigence and unwillingness to open itself to Japan and see Japan as its equal, was an egregious insult. To the Yi court, which defined itself as a loyal tribute state to China, Japan's newfound belief in itself as "modern" was equally bizarre; its request for relations outside the hierarchical structure of Great Tradition statecraft was downright arrogant. Thus grudges were nursed by both sides from the first rumblings of Japan's eagerness to adopt a bigger role in the world as a united nation. Some Meiji leaders opted, after the initial Korean brush-off of the 1860s, to "subdue" the country and thus avenge the earlier slight. Yet not all were of one mind as to how to go about "subduing" Korea. Initial plans called for a punitive invasion that would double as a diversionary tactic for the Government to draw the attention of disenfranchised Samurai away from the recent moratorium on their government stipends. ${ }^{60}$

Fortunately for Korea, the non-interventionists within Meiji cabinets of the early 1870 s gained a deciding hold over Korea policy. Consequently, the mention of such an expedition was dropped out of concern that Japan was not yet strong enough to tackle the Qing over Korea as well as concern over the reaction of Western powers. Less emotional circumstances than returning a diplomatic slight were also at the forefront of emerging Japanese policy toward Korea. Great Power activity in the area convinced many Japanese leaders early on of the necessity for a special Japanese relationship with the peninsula, since monopolization of Korea by untrustworthy Westerners would severely impinge on Japan's own security. Such talk had begun in earnest with the arrival of a Russian warship at Tsushima prior to the Restoration. ${ }^{61}$ It had only grown in the context of Japan's emerging modernization and Korean rebuffs to Japanese requests of normal relations subsequent to 1868.

Aspirations among many Meiji era politicians and thinkers for a technological and cultural uplifting of Korea under Japanese aegis were equally strong persuaders for an interventionist policy toward the country. Korean regent Taewongun's refutation of Japan's description of itself as achieving modernity caused Meiji opinion-makers to defensively disparage Korean culture, knowledge of the outside world, and technological prowess. Such invidious comparisons of Japan to Korea were not an end in themselves, rather, many prominent voices inside and outside of the government hoped, Korea could be changed from the inside out under the watchful eye of Japan. Just as in Taiwan, almost all Meiji personalities recognized the inherent cultural similarity between 
Japan and Korea but used this acknowledged similarity to lend urgency to their desire to modernize Korea through means of Korea's own "Restoration", via Japanese tutelage. ${ }^{62}$

These feelings of highly paternalistic sympathy among some Japanese elites for Korea remained after Japan wrangled open select Korean treaty ports after 1876 - an act that was rightly seen as echoing the forcing of Western "unequal treaties" upon Japan in the 1850s and 1860s. ${ }^{63}$ Nevertheless, close comparisons came to be made by Meiji oligarch's between the Korea they encountered and their own fresh memory of Japan's recent past. Fukuzawa Yukichi, a junior ranking Samurai/turned Restorationist/turned founder of Japan's largest private university, sentimentally compared the visit of a Korean delegation to Japan in 1881 with Japan's 1861 mission to the West in which Fukuzawa had played a part. $^{64}$ Even Fukuzawa's ruminations about a preferred Japanese approach to Korea began to harden. They were expressed most clearly in his memoirs where he urged Japan to "get out of Asia" and begin to treat less civilized Asian nations as contemptuously as did the West. ${ }^{65}$

The geopolitical considerations that had framed the earlier debate over punitive action against Korea in 1873 were again raised by Imperial Army Chief of Staff Yamagata Aritomo in 1902 after Qing China's 1895 defeat in the First Sino-Japanese War. Yamagata echoed his Prussian advisor's earlier estimation of Korea as "a dagger" pointed at the home-islands. ${ }^{66}$ To the minds of Yamagata and his like-minded peers, the only suitable way to sheath the offending dagger was through outright Japanese control.

China's defeat not only removed a significant contender with Japan for power in Korea. The very idea that "upstart" Japan could defeat Asia's largest land-based Empire gave further credence to the growing belief that Japan was the new center of East Asian power. By virtue of China's humiliation, some thought it should also become the towering example of modernity for the emulation of Japan's neighbors.

Supporters of Japanese Korea policy championing reform - as distinct from colonial conquest - still maintained sufficient political support to fend off the likes of Yamagata and others, but the primary exponent of reform, Prime Minister Ito Hirobumi, felt compelled to reach a happy medium with harder edged elements of the government. The result was a Japanese Protectorate begun in 1905 after the defeat of Russia, overseen by a Japanese Resident General. The continuing Korean behavior of playing Japan off against other competing powers occasioned an initial Japanese response to Korea's annexation in 1910, every bit as brutal as the bandit-suppression raids seen in Taiwan. ${ }^{67}$ The Japanese response to anti-Japanese resistance was likely as brutal as it was owing to 
the very different nature of the Korean resistance from that on Taiwan. Whereas Taiwan's peripheral relationship to China's central government and the ruling ethic of self interest on the island diffused resistance, the reality of Korea as a kingdom of its own focused resistance as it could never be in Taiwan. The main form of colonial Korea's first violent opposition, the wibyong, or Righteous Army, concentrated the energies of Japanese forces. ${ }^{68}$ The perception on the part of Japanese authorities that they oversaw a colony that was essentially an armed and hostile country deserving only of military Governorship and administrative independence from the metropole government was thus easily reinforced. Early Japanese governance of Korea then proceeded along similar lines as early governance of Taiwan with one major exception. Anti-Japanese demonstrations in May 1919 in Korea, following similar protests in China, led to calls among Japanese intelligentsia in the home islands for more enlightened colonial government that would truly live up to the ideal of isshi-doujin. Ironically, the reforms were never applied to Korea, though slight modifications were made to the relationship between the Home Government and Taiwan's Government-General. Indeed, some historians have noted that the only change in Korea's government was purely cosmetic. For a decade and a half after 1919 the colony's military governors made public appearances in civilian attire rather than in customary uniform. ${ }^{69}$

The basic outline of early Japanese colonialism in Korea remained similar to that on Taiwan, yet there were differences. In the realm of education, the authorities copied the Taiwan Governor General's toleration of native language schools as well as government's careful cultivation of good relations with Confucian scholarly elites. However, Korea went through a brief period of nationalism during the late Yi Dynasty with the beginning of the "education for the nation" movement. Here, the Dynasty encouraged the growth of county schools that included some topics relating to the reality of the wider world in its curriculum. ${ }^{70}$ Nothing resembling the Korean movement of the late Yi period, as abortive as it may well had been, ever existed on Taiwan. This meant that Taiwan authorities' goals were relatively straightforward: undermine the private schools and increase enrollment to Japanese funded schools. In Korea, however, Japanese officials needed to achieve this overarching goal not only without goading the classically Chinese educated yangban class into resistance, but also while trying to undercut the country schools which were acute incubators of Korean nationalism and anti-Japanese feeling. The same approach that had been tried on Taiwan eventually ended the danger to Japanese mandated Korean education posed by the "education for the nation" movement. A strong national identity - a perhaps-natural outcome from six centuries of control by one dynasty over a single, ethnically homogenous people - could not, however, be so 
easily overcome. In a situation directly opposite to the one in Taiwan - where a Japanese education eventually became an accepted part of life for most islanders and was even accepted by traditional elite, Korea proved more difficult. Although yangban opposition to Japan may not have been singularly notable - perhaps a sign that Japan's early courting of this Korean elite did what it was calculated to do - other sources of Korean identity threw up roadblocks to Japanese efforts to extend and deepen their control. Christian missionaries, long active in Yi Dynasty Korea continued to be active after annexation although relations between them and the Japanese, initially pleasant if not cordial, declined. Japanese authorities were continually irritated at missionary accounts of Japanese actions that were not always according to the interpretation most welcomed by the Governor General. ${ }^{71}$ More to the point, mission schools competed with Japanese run "ordinary schools" for students among the mass of the Korean population, challenging the commonplace Meiji and Taisho era Japanese conceit that modernity could only be wrought in the colonies through exclusively Japanese leadership and education, Christian schools also competed with Japanese institutions and were among the first sources of Western scientific and political ideas in the peninsula.

The kominka movement, previously described mainly in the Taiwanese context, had summarily different effects, and evoked a customarily different reaction due to a number of reasons including historical Korean cultural cohesion and the memory of an equally cohesive indigenous precolonial political order.

The insistence of Korean Government General officials on a literal oath for recitation among Koreans bespeaks the lower expectation among colonial officials of Koreans' capacity for quick assimilation at the campaign's outset. The "national language" movement to supplant Korean with Japanese seems to have been more coercive than the corresponding effort in Taiwan. Responsibility for the existence of a much more coercive policy may not have lain with Japanese alone. Undoubtedly, authorities expected that any attempt to diminish the standing of Korean in favor of Japanese would undoubtedly be greatly resisted by the people - as indeed it was - thus, a more gentle, persuasive policy was doomed to certain failure and only sufficient force could guarantee compliance. Confidence in Taiwan's population for compliance by authorities there seemed to have been much greater, as implied by the absence of a loyalty oath, and a coercive campaign that was unnecessary on the island. ${ }^{72}$

"Religious reform," the institution of State Shinto in Korea, fared about as well as in Taiwan although Korean unwillingness to adopt even perfunctory obeisance to Shinto was marked while 
even Taiwanese Christians paid lip service to the Emperor's position as descendent of Amaterasu Omikami. ${ }^{73}$ The prevalence of Christianity, particularly evangelical sects within Korea, made participation by most Korean Christians in Shinto rites or obsequiousness to the Emperor as earthly intercessor to the Shinto pantheon, tantamount to worship in a false religion. The "name changing" campaign, however, evinced the most widespread and dramatic accounts of Korean distress. The practical effect of the campaign followed the one in Taiwan - those having adopted Japanese names usually retained in their new name some form of reference to their indigenous name. Yet Taiwanese acceptance of new names was largely absent in Korea. The immediate Korean reaction was one of grief at the perceived loss of filial ties with ancestors upon their adoption of new names. ${ }^{74}$

\section{Conclusion}

Altogether, Japanese colonizers advanced remarkably similar rationales in each of Japan's two biggest colonies. The early emphasis on association and a gradual merger of each colonial populace into the empire was replaced due to the vicissitudes of the changing international situation and Japan's place within it. Such changes disrupted the slow process of colonial maturation to the ideal of the metropole. The change was exemplified by the urgency inherent in the aims for quick cultural parity between Japan and the colonies and an increased need for colonial assistance in war, found in kominka pronouncements nearing the end of the Empire.

Specific changes in Japanese governance occurred in each colony, both as a result of each locale's pre-colonial history - which predisposed each colony for either relative docility or obstinacy toward Japanese rule - and the colonial authorities' reaction to it. Though certain policies carried out were virtually identical in intent, and even in name, their application was substantially different due to the colonial peoples' cultural and historical make-up, Japanese responses, and different concerns regarding each colony among political leaders in the home islands.

\footnotetext{
${ }^{1}$ Mark R. Peattie, "Introduction," in The Japanese Colonial Empire, 1895-1945, eds. Ramon H. Myers, and Mark R. Peattie. (Princeton NJ: Princeton University Press). 1984, pp. 6-8

${ }^{2}$ Peattie, “Introduction,” pp 8-10.

${ }^{3}$ Peattie, "Introduction," pg 14.

${ }^{4}$ Chen, I-Ten Edward. "Japanese Colonialism in Korea and Formosa: A Comparison of The Systems of Political Control," Harvard Journal of Asian Studies 30 (1970), pg 128.

There were eight Governor Generals of Korea, two were appointed twice. Besides the wholly military identity of Japan's Korea proconsuls, the office of Korea Governor General appears to have been reserved for military men of political as well as martial consequence. Chen notes that three of the six Governors appointed from 1919-1945 were past or future Prime Ministers. The first Governor, Terauchi Masatake, had been Minister of the
} 
Army prior to his taking up office in Seoul as was future Governors Yamanashi Hanzo, in Korea from 1927-1929 and Ugaki Kazushige, in Korea from 1931-1936 and Minami Jiro, in Korea from 1936-1942.

${ }^{5}$ Chen, “Japanese Colonialism in Korea and Formosa: A Comparison of The Systems of Political Control," pg 156.

${ }^{6}$ Roy, Denny. Taiwan: A Political History. Ithaca NY: Cornell UP, 2003, pp 12-15

Roy notes the first major mainland Chinese interest in Taiwan as beginning with the shipwrecking of Admiral Cheng Ho on the island during his voyages back to China from SE Asia. Official mainland government policy forbade Chinese emigration to the island after the Admiral's return to China. Punishment for flouting of the restriction was death.

${ }^{7}$ Roy, Taiwan: A Political History, pp 15-17

Dutch rule was begun with the defeat of Spanish forces on Taiwan near modern day Tamsui in 1644. Dutch East Indies Company troops would be garrisoned at present day Tainan at the Casteel Zeelandia abutting the city's harbor.

${ }^{8}$ Roy, Taiwan: A Political History, pg 17

${ }^{9}$ Roy, Taiwan: A Political History, pp 18-19

${ }^{10}$ Roy, Taiwan: A Political History, pg 21

Tensions were not solely between islanders and mainland officials or between Chinese and aborigines tensions between Chinese migrants differentiated from one another by region of origin or identity as distinctive people existed as well. Fujianese from Fujian and Hakka refugees, most having fled China for Taiwan after the defeat in 1864 of the Hakka-led Taiping Rebellion, distrusted one another. However even Fujianese from rival areas - namely the cities of Zhangzhou and Quangzhou - were known to clash.

${ }^{11}$ Philips, Steven E. Between Assimilation and Independence: The Taiwanese Encounter Nationalist China, 19451950. Stanford CA: Stanford UP, 2003,pg 5.

${ }^{12}$ Roy, Taiwan: A Political History, pp 29-30

Though Qing officials saw fit to temporize before deciding to incorporate Taiwan as a full fledged province, French inroads on the island in 1885 forced the hand of those advocating the island's administrative inclusion.

${ }^{13}$ Philips, Steven E. Between Assimilation and Independence, pg 4

${ }^{14}$ Philips, Steven E. Between Assimilation and Independence, pg 5

${ }^{15}$ Duus, Peter. The Abacus and the Sword: The Japanese Penetration of Korea, 1895-1910. Berkeley CA: University of California Press, 1995, pg 33, and Mark R. Peattie, "Introduction," in Myers et al, pp. 15-16

${ }^{16}$ Chen, I-Ten Edward. “Japan's Decision to Annex Taiwan: A Study of Ito-Mutsu Diplomacy, 1894-95.," The Journal of Asian Studies 37, No.1 (Nov., 1977), pp 64-65

Chen notes that Foreign Minister Mune Munemitsu was far more sanguine about the possibility of Western intervention in the event of Japan's capture of Peking. He admitted the possibility of such intervention but believed that public pressure from within Japan, bordering on pro-war hysteria, would make the government's attempt to awaken the public to the danger nigh impossible. Instead of diverting military efforts away from Peking however, Munemitsu argued that the Army continue its overland advance into mainland China. Western intervention would be dealt with one way or another if it actually materialized. In the final analysis Prime Minister Ito's fears were well grounded as the Triple Intervention - which divested Japan of its post war holding on the Liaotung Peninsula - bore out. 
${ }^{17}$ Chen, "Japan’s Decision to Annex Taiwan: A Study of Ito-Mutsu Diplomacy, 1894-95.," pp 65-66 and Roy, Taiwan: A Political History, pg 32.

Inoue Tsuyoshi, one of Ito's advisors, is also credited with raising Taiwan's strategic importance to Japan's territorial defense. Inoue opined that; "Taiwan...can control maritime rights to the Yellow Sea, the North China Sea, and the Sea of Japan. It is the door to Japan's defense. If we lose this good opportunity, the island of Taiwan will be taken by other powerful countries within two or three years."

${ }^{18}$ Duus, The Abacus and the Sword, pp 29-30.

${ }^{19}$ Lamley, Harry J. "Taiwan Under Japanese Rule, 1895-1945: The Vicissitudes of Colonialism,” in Taiwan: A New History, ed. Murray Rubinstein. (Armonck N.Y: M.E. Sharpe). 1999, pg 207

Lamley notes that resistance to the incoming Japanese was very fragmented with the most effective resistance given by Lin Shao Mao's and Liu Yung-fu's militias composed of local and mainland Chinese voluntary fighters. Liu and other members of his "Black Flag" militia attempted to assert an abortive "Taiwan Republic" based out of the former provincial capital of Tainan. By mid October 1895, four months since the initial Japanese landings on Taiwan at Keelung and Taipei, the Japanese commander and newly appointed military governor of Taiwan, Admiral Kabayama Sukenori, declared hostilities to have ended with Liu's defeat and Tainan's fall on October 21. Counter-insurgency operations by Japanese forces continued with the island on an effective war footing long after Kabayama's declaration however. According to estimates given close to 12,000 people, classified by colonial authorities as "bandit-rebels" were killed between 1898 and 1902, about twice as many inhabitants as those who died during the initial Japanese invasion in 1895. These civilian casualty figures are presented out of a total island population estimated at just under three million near the end of the nineteenth century.

${ }^{20}$ Roy, Taiwan: A Political History, pg 35

${ }^{21}$ Takekoshi, Yosaburo. Japanese Rule in Formosa. Trans. George Braithwaite. New York: Longmans, Green, and Co, 1907, pg 94.

${ }^{22}$ Roy, Taiwan: A Political History, pg 35.

${ }^{23}$ Tse-Han, Lai, Myers, Ramon H., and Wou, Wei. A Tragic Beginning: The Taiwan Uprising of February 28, 1947. Stanford CA: Stanford UP, 1991, pg 15 and Roy, Taiwan: A Political History, pg 34.

${ }^{24}$ Takekoshi, Japanese Rule in Formosa, pg 96.

${ }^{25}$ Mark R. Peattie, “Japanese Attitudes Toward Colonialism, 1895-1945," in The Japanese Colonial Empire, 18951945, eds. Ramon H. Myers, and Mark R. Peattie. (Princeton NJ: Princeton University Press). 1984, pp. 82-87.

Goto's belief in the applicability of science to colonial administration was echoed by one of his biggest promoters in both Japan and the West, Diet member Takekoshi Yosaburo. Takekoshi insisted that "biological laws prevail in politics as well as in the human body.....We of the latter-day school of the science of government firmly believe that the government of a colony cannot go beyond biological laws...."

${ }^{26}$ Peattie, “Japanese Attitudes Toward Colonialism,” pp 84-85.

${ }^{27}$ Takekoshi, Japanese Rule in Formosa, pp 21-22.

${ }^{28}$ Peattie, “Japanese Attitudes Toward Colonialism,” pg 95.

${ }^{29}$ Peattie, "Japanese Attitudes Toward Colonialism," pg 94.

${ }^{30}$ Lamley, Harry, "Assimilation Efforts in Taiwan: The Fate of the 1914 Movement," in Monumenta Serica, Vol. XXIX (17-71), pp. 496-500. 
${ }^{31}$ Chen, Ching-Chih. The Japanese Adaptation of the Pao-Chia System in Taiwan, 1895-1945," in The Journal of Asian Studies, 34, No.2 (February., 1975), pp 391-394.

${ }^{32}$ Chen, “The Japanese Adaptation of the Pao-Chia System in Taiwan," pp 395-396

${ }^{33}$ E. Patricia Tsurumi, "Colonial Education in Korea and Taiwan," in The Japanese Colonial Empire, 1895-1945, eds. Ramon H. Myers, and Mark R. Peattie. (Princeton NJ: Princeton University Press). 1984, pp 283-284

${ }^{34}$ Tsurumi, "Colonial Education in Korea and Taiwan,” pp 282-284

${ }^{35}$ Tsurumi, "Colonial Education in Korea and Taiwan," pg 293.

${ }^{36}$ Roy, Taiwan: A Political History, pg 45

${ }^{37}$ Peattie, "Japanese Attitudes Toward Colonialism," pp 97-99 Isshi-Doujin began life as a phrase describing the ideal of impartial government toward all subjects in Chinese before the phrase's use in modern Japanese. The Chinese antecedent to the Japanese isshi-doujin was $i$-shih t'ung-jen meaning "to be equally merciful to all," or to "grant an impartial favor or kindness." The phrase was used by Chinese scholars and poets in the Tang Dynasty (618-907AD).

${ }^{38}$ Peattie, "Japanese Attitudes Toward Colonialism," pp 100-101 Peattie claims Mochiji's thoughts on assimilation foreshadowed later policy such as the Kominka movement by noting that Mochiji himself asserted that assimilation through cultural interactions between Japanese and their subject peoples would be integral to the integrity and enlargement of the Empire. Peattie quotes Mochiji as stating that "[Upon] the solution of this profound problem [of cultural integration], lies the fate and direction of the expanding Japanese empire."

${ }^{39}$ Chen, Edward I-te, "The Attempt to Integrate the Empire: Legal Perspectives," in The Japanese Colonial Empire, 1895-1945, eds. Ramon H. Myers, and Mark R. Peattie. (Princeton NJ: Princeton University Press). 1984, pp 240245

${ }^{40}$ Takekoshi, Japanese Rule in Formosa, pp 23-24.

${ }^{41}$ Chen, I-Ten Edward. "Japanese Colonialism in Korea and Formosa: A Comparison of The Systems of Political Control,” Harvard Journal of Asian Studies 30 (1970), pg 137

${ }^{42}$ Chen, “Japanese Colonialism in Korea and Formosa," pp127-128, 131-135.

${ }^{43}$ Lamley, “Assimilation Efforts in Taiwan,” pg 501.

${ }^{44}$ Peattie, “Japanese Attitudes Toward Colonialism,” pp 102, 109-114

${ }^{45}$ Chou, Wan-yao. "The Kominka Movement in Taiwan and Korea: Comparisons and Interpretations," in The Japanese Wartime Empire, 1931-1945, eds. Peter Duus, Ramon H. Myers, and Mark R. Peattie. (Princeton NJ: Princeton University Press). 1996, pp 40-42

${ }^{46}$ Chen, "Japanese Colonialism in Korea and Formosa," pp 130-131

${ }^{47}$ Chou, “The Kominka Movement in Taiwan and Korea," pg 44.

${ }^{48}$ Chou, "The Kominka Movement in Taiwan and Korea," pp 42-43 The oath was officially promulgated on October $2^{\text {nd }}, 1937$ and called the "Oath as Subjects of the Imperial Nation." The oath for adults consisted of three statements all professing loyalty to the Empire as filial subjects. Oath takers vowed to "repay His Majesty as well as the country with loyalty and sincerity", to "love, trust, and help one another to strengthen our unity," and to "endure hardship, train ourselves, and cultivate strength so that we can exalt the imperial way." 
${ }^{49}$ Chou, "The Kominka Movement in Taiwan and Korea," pg 45

${ }^{50}$ Chou, “The Kominka Movement in Taiwan and Korea," pp 45-46 and Roy, Taiwan: A Political History,pg 43.

${ }^{51}$ Chou, "The Kominka Movement in Taiwan and Korea," pg 46. Admiral Hasegawa Kiyoshi replaced Admiral Kobayashi as Governor in late 1940 and ended the policy soon after he took up the post.

${ }^{52}$ Chou, "The Kominka Movement in Taiwan and Korea," pp 50-51

${ }^{53}$ Chou, "The Kominka Movement in Taiwan and Korea," pp 44 and 51.

${ }^{54}$ Ching, T.S, Becoming Japanese: Colonial Taiwan and the Politics of Identity Formation, pg 95. Ching notes that the Taiwan colonial government did attempt to undermine the use of Taiwanese dialects - principally the Min-Nan dialect spoken by the island's majority Fujianese population - through coercive means as well as compulsive strategies to encourage use of Japanese. In May 1937 the Government-General's Education Office promulgated a decree that "those who use the Taiwanese language are subject to fines." In Taichu province, midway down Taiwan's west coast, all civil servants were prohibited from speaking local dialects and those who did not practice speaking Japanese in villages near Taihoku (Taipei) were fined for "laziness." In the office of the port of Karenko (Hualien), those Taiwanese discovered speaking any language other than Japanese were fired on the spot.

${ }^{55}$ Chou, “The Kominka Movement in Taiwan and Korea," pp 55-59.

${ }^{56}$ Chou, "The Kominka Movement in Taiwan and Korea," pp 67-68

${ }^{57}$ Chou, "The Kominka Movement in Taiwan and Korea," pp 63-65

${ }^{58}$ Buzo, Adrian. The Making of Modern Korea. New York: Routledge, 2002.

${ }^{59}$ Duus, The Abacus and the Sword, pp 29-31

${ }^{60}$ Duus, The Abacus and the Sword, pp 38-43

${ }^{61}$ Duus, The Abacus and the Sword, pg 33

${ }^{62}$ Duus, The Abacus and the Sword, pp 51-60

${ }^{63}$ Duus, The Abacus and the Sword, pp 43-47

${ }^{64}$ Duus, The Abacus and the Sword, pg 53 Fukuzawa is quoted as writing to a friend of the arrival of the Korean delegation as "arrived to observe conditions in Japan, two of them are enrolled in our academy....When I think about myself twenty-odd years ago, I cannot help feeling sympathy and compassion for them.... When I hear them talk, it is Japan of thirty years ago."

${ }^{65}$ Marius B. Jansen, “Japanese Imperialism: Late Meiji Perspectives,” in The Japanese Colonial Empire, 1895 1945, eds. Ramon H. Myers, and Mark R. Peattie. (Princeton NJ: Princeton University Press). 1984, pg 71.

${ }^{66}$ Harries, Meirion and Susie. Soldiers of the Sun: The Rise and Fall of the Imperial Japanese Army, New York: Random House, 1991, pg 53.

${ }^{67}$ Duus, The Abacus and the Sword, pp 69-79

${ }^{68}$ Duus, The Abacus and the Sword, pp 220-234 Korean dissatisfaction with the imposition of Japanese sponsored government policies implemented during the Protectorate, animosity toward Japan across the nation. Tax laws which fixed the population's annual tribute to Seoul was thought by many Koreans to accrue only to the eventual benefit of Japanese. Local Korean elites spearheaded this resentment as well as opposition to a land valuation 
similar to that undertaken in early Meiji era Japan. In 1906 Min Chong-sik, a relative of the pro-Chinese Korean Queen Min, assassinated on the order of Japanese officials in 1897, took to fighting a rearguard guerilla war against Japanese forces. Disaffected and demobilized units of the former Korean Army rallied to the rebels the following year, though all insurgents were steadily hunted by Japanese troops. Several thousand strong by 1908, the rebel armies or Uibyong -"righteous armies" panicked some Japanese civilians. A Japanese settler reported to Resident General Ito in December 1907 that "ordinary people cannot live on doing their daily work. Some are fleeing with their families, some have been killed, some have lost their homes. Now there is cold and starvation. It is a calamitous situation. Japanese residents are all retreating from the interior."

${ }^{69}$ Chen, "Japanese Colonialism in Korea and Formosa," pg 128

${ }^{70}$ Tsurumi, “Colonial Education in Korea and Taiwan,” pp 295-296

${ }^{71}$ Tsurumi, “Colonial Education in Korea and Taiwan,” pg 297

${ }^{72}$ Chou, "The Kominka Movement in Taiwan and Korea," pg 43

${ }^{73}$ Chou, "The Kominka Movement in Taiwan and Korea,"pp 45-46

${ }^{74}$ Kim, Richard. Lost Names: Scenes from a Korean Boyhood. University of California Press, Berkeley CA, 1998, pp 87-115 


\section{Bibliography}

Buzo, Adrian. The Making of Modern Korea. New York: Routledge, 2002.

Carter, J. Eckert, "Total War, Industrialization and Social Change in Late Colonial Korea," in The Japanese Wartime Empire, 1931-1945, eds. Peter Duus, Ramon H. Myers, and Mark R. Peattie. (Princeton NJ: Princeton University Press). 1996, pp. 3-39

Chen, I-Ten Edward. "Japanese Colonialism in Korea and Formosa: A Comparison of The Systems of Political Control," Harvard Journal of Asian Studies 30 (1970): 126-158.

Chen, I-Ten Edward. “Japan's Decision to Annex Taiwan: A Study of Ito-Mutsu Diplomacy, 1894-95.," The Journal of Asian Studies 37, No.1 (Nov., 1977): 61-72

Duus, Peter. The Abacus and the Sword: The Japanese Penetration of Korea, 18951910. Berkeley CA: University of California Press, 1995

Duus, Peter, Myers, Ramon H., Peattie, Mark R., eds. The Japanese Wartime Empire, 1931-1945. Princeton NJ: Princeton University Press, 1996.

Chou, Wan-yao, "The Kominka Movement in Taiwan and Korea: Comparisons and Interpretations," in The Japanese Wartime Empire, 1931-1945, eds. Peter Duus, Ramon H. Myers, and Mark R. Peattie. (Princeton NJ: Princeton University Press). 1996, pp. 42-68

Harries, Meirion and Susie. Soldiers of the Sun: The Rise and Fall of the Imperial Japanese Army, New York: Random House, 1991.

Kim, Richard. Lost Names: Scenes from a Korean Boyhood. University of California Press, Berkeley CA, 1998.

Lamley, Harry J. "Assimilation Efforts in Taiwan: The Fate of the 1914 Movement," in Monumenta Serica, Vol. XXIX (17-71)

Lamley, Harry J. "Taiwan Under Japanese Rule, 1895-1945: The Vicissitudes of Colonialism," in Taiwan: A New History, ed. Murray Rubinstein. (Armonck N.Y: M.E. Sharpe). 1999 
Myers, Ramon H., Peattie, Mark R., eds. The Japanese Colonial Empire, 18951945. Princeton NJ: Princeton University Press, 1984.

Chen, Edward I-te, "The Attempt to Integrate the Empire: Legal Perspectives," in The Japanese Colonial Empire, 1895-1945, eds. Ramon H. Myers, and Mark R. Peattie. (Princeton NJ: Princeton University Press). 1984.

Marius B. Jansen, "Japanese Imperialism: Late Meiji Perspectives," in The Japanese Colonial Empire, 1895-1945, eds. Ramon H. Myers, and Mark R. Peattie. (Princeton NJ: Princeton University Press). 1984, pp. 61-79.

Mark R. Peattie, "Japanese Attitudes Toward Colonialism, 1895-1945," in The Japanese Colonial Empire, 1895-1945, eds. Ramon H. Myers, and Mark R. Peattie. (Princeton NJ: Princeton University Press). 1984, pp. 80-127

E. Patricia Tsurumi, "Colonial Education in Korea and Taiwan," in The Japanese Colonial Empire, 1895-1945, eds. Ramon H. Myers, and Mark R. Peattie. (Princeton NJ: Princeton University Press). 1984, pp. 275-311

Rhee, M.J. Doomed Empire: Japan in Colonial Korea. Aldershot U.K: Ashgate Publishing Ltd, 1997.

Roy, Denny. Taiwan: A Political History. Ithaca NY: Cornell UP, 2003.

Rhee, M.J. Doomed Empire: Japan in Colonial Korea. Aldershot U.K: Ashgate Publishing Ltd, 1997.

Roy, Denny. Taiwan: A Political History. Ithaca NY: Cornell UP, 2003.

Philips, Steven E. Between Assimilation and Independence: The Taiwanese Encounter Nationalist China, 1945-1950. Stanford CA: Stanford UP, 2003. 